\title{
Penggunaan Model Pembelajaran STAD (Student Team Achievement Division) untuk Meningkatkan Kemampuan Membaca Pemahaman Peserta Didik Kelas III Sekolah Dasar
}

\section{Rivenski Mia Abdini}

Universitas Sebelas Maret

miaabdinirivenski@gmail.com

Article History

received 30/4/2021

\begin{abstract}
The purpose of this research was to improve comprehension reading ability, through used STAD (Student Team Achievement Division) learning model for $3^{\text {rd }}$ grade of elementary school student on 2020/2021 academic year. This study was a classroom action research. The subjects of this study were class teacher and 31 students from $3^{\text {rd }}$ grade of elementary school student. The procedure of this research consisted of 2 cycles; each cycle consisted of 2 learning process. The stages of each cycle are planning, implementing, observing and reflecting. Data collection of this research was done by interviewing, observing, comprehension reading ability testing, and documenting technique. The classical average of the first cycle was 69,1 and 48,39\% students passed comprehension reading ability test. At the second cycle, the classical average increased to 76,83 and the number of students who passed comprehension reading ability test also increase to $83,87 \%$. Based on the result of this study, it concluded that STAD (Student Team Achievement Division) learning model could increase the comprehension reading ability of $3^{\text {rd }}$ grade of elementary school student.
\end{abstract}

Keywords: comprehension reading ability, STAD learning model, elementary school

\section{Abstrak}

Tujuan dari penelitian ini yaitu untuk meningkatkan kemampuan membaca pemahaman dengan menerapkan model pembelajaran STAD (Student Team Achievement Division) pada peserta didik kelas 3 sekolah dasar tahun ajaran 2020/2021. Penelitian ini berbentuk Penelitian Tindakan Kelas (PTK). Subjek dari penelitian ini yaitu guru kelas dan 31 peserta didik kelas III sekolah dasar. Prosedur penelitian ini terdiri atas dua siklus; tiap siklusnya terdiri dari dua pembelajaran. Tahap penelitian tiap siklusnya yaitu perencanaan, tindakan, observasi, dan refleksi. Teknik pengumpulan data dari penelitian ini dilakukan dengan wawancara, observasi, tes membaca pemahaman, dan dokumetasi. Rata-rata klasikal pada siklus I yaitu 69,1 dan $48,39 \%$ peserta didik lolos tes kemampuan membaca pemahaman. Pada siklus II, rata-rata klasikal naik menjadi 76,82 , selain itu jumlah peserta didik yang lolos tes kemampuan membaca pemahaman juga naik menjadi $83,87 \%$. Berdasarkan hasil penelitian tersebut, dapat disimpulkan bahwa model pembelajaran STAD dapat meningkatkan kemampuan membaca pemahaman pada peserta didik kelas 3 sekolah dasar

Kata kunci: kemampuan membaca pemahaman, model pembelajaran STAD, sekolah dasar 


\section{PENDAHULUAN}

Perkembangan zaman yang begitu cepat menjadikan bacaan sebagai salah satu media/ sarana utama yang digunakan manusia untuk mengetahui dan memahami informasi, memperluas pengetahuan, serta menjadi sarana hiburan. Konsep membaca tidak lagi hanya berlandasan pada konteks berpikir atas membaca tekstual, melainkan sudah sudah melibatkan dunia informasi dan media elektronik (Saefudin, 2015). Oleh karena itu, kemampuan membaca yang baik penting untuk dimiliki peserta didik agar mereka bisa mengikuti dan beradaptasi dengan zaman yang semakin maju. Selain itu, membaca kemampuan membaca juga penting untuk menunjang keberhasilan peserta didik dalam memahami mata pelajaran lainnya. Kemampuan membaca pemahaman ialah potensi seseorang dalam menguasai suatu bacaan (secara kognitif) yaitu untuk memahami maksud, ide pokok, maupun hal-hal penting lainnya yang ada pada bacaan (Desmita, 2012; Mulyasa, 2008; Khundaru, 2014).

Wawancara pratindakan dilakukan pada tanggal 20 Januari 2021, sedangkan observasi pratindakan dilakukan pada 27 Januari 2021. Simpulan dari kegiatan pratindakan yang telah dilakukan yaitu peserta didik kelas III mempunyai kemampuan membaca pemahaman yang masih rendah. Rendahnya kemampuan membaca pemahaman peserta didik disebabkan belum maksimalnya penerapan model pembelajaran yang digunakan oleh guru. Selain itu, bacaan yang terlalu panjang dan tidak menarik memberi kesan sulit, sehingga peserta didik kurang bersemangat dalam mengikuti pembelajaran membaca pemahaman. Belum optimalnya kamampuan membaca pemahaman peserta didik kelas III perlu dicarikan alternatif agar kemampuan membaca pemahaman peserta didik semakin baik.

Peneliti menerapkan salah satu model inovatif yaitu model pembelajaran STAD (Student Team Achivement Division) sebagai upaya untuk meningkatkan kemampuan membaca peserta didik kelas III. Model Pembelajaran STAD (Student Team Achievement Division) adalah model pembelajaran yang menyajikan materi secara sederhana dan menekankan pada kerja kelompok dalam menyelesaikan LKPD (Rusman, 2014; Slavin, 2015). Model STAD menjadikan keaktifan peserta didik dapat tersalurkan dengan baik dan adanya partisipasi peserta didik menjadikan pembelajaran lebih berkesan/ bermakna, sehingga keterampilan, pengalaman, dan kemampuan peserta didik dapat berkembang/ meningkat (Khalid Khalaf; 2018).

Berdasarkan penjelasan di atas, maka tujuan dari penelitian ini yaitu meningkatkan kemampuan membaca pemahaman peserta didik kelas III melalui penerapan model pembelajaran STAD (Student Team Achievement Division). Model pembelajaran STAD dapat membiasakan peserta didik untuk terlibat langsung dalam menemukan informasi/ hal-hal penting dalam bacaan. Selain itu, model pembelajaran ini juga dapat membiasakan peserta didik untuk bekerjasama dan berani dalam mengungkapkan ide/ gagasan yang mereka temukan.

\section{METODE}

Penelitian ini menggunakan pendekatan kualitatif dengan jenis penelitian yaitu PTK atau Penelitian Tindakan Kelas. Penelitian ini dilaksanakan di SD Negeri 2 Dibal, Kecamatan Ngemplak, Kabupaten Boyolali. Jangka waktu penelitian ini mulai dari Januari sampai Juli 2021. Subjek pada penelitian ini yaitu guru dan 31 peserta didik kelas III. Pengumpulan data dilakukan melalui teknik wawancara, observasi, tes 
kemampuan membaca pemahaman, dan dokumentasi. Penelitian ini menggunakan teknik validitas berupa validitas isi, triangulasi sumber, dan triangulasi teknik. Analisis data kuantitatif pada penelitian ini dilakukan dengan menggunakan model deskriptif komparatif, sedangkan analisis data kualitatif dilakukan dengan menggunakan model interaktif (Miles dan Huberman). Tahapan dari model analisi Miles dan Huberman yaitu 1) reduksi data; 2) penyajian data dalam bentuk grafik, tabel, atau deskripsi singkat; 3) penarikan kesimpulan (Sugiyono, 2010). Indikator kinerja penelitian ini sebesar $80 \%$ atau sejumlah 25 peserta didik masuk kategori tuntas (nilai $\geq 70$ ).

\section{HASIL DAN PEMBAHASAN}

Penelitian ini dilaksanakan dalam dua siklus. Tiap siklut terdiri atas dua pertemuan. Pelaksanaan tindakan tiap pertemuan terdiri atas 3 kegiatan pembelajaran, yaitu kegiatan pembuka, inti, dan penutup. Kegiatan inti dari pembelajaran menerapkan sintaks model pembelajaran STAD (Student Team Achievement Division). Sintaks model pembelajaran STAD menurut Huda (2015), Rusman (2014) dan Slavin, (2015) dijelaskan sebagai berikut : 1) Peserta didik dibagi dalam kelompok kecil; 2) Peserta didik diberi informasi mengenai tujuan pembelajaran hari itu; 3) Peserta didik dibagikan lembar kerja; 4) peserta didik bekerja sama dalam menyelesaikan LKPD; 5) Guru melakukan bimbingan kelompok; dan 6) Peserta didik mempresentasikan hasil pekerjaan kelompok mereka; 7) Peserta didik dan guru membuat simpulan. Tes kemampuan membaca pemahaman dilaksanakan pada kegiatan penutup. Efektifitas model STAD untuk mengtasi masalah rendahnya kemampuan membaca pemahaman dibuktikan dengan meningkatnya kemampuan membaca pemahaman pada tiap siklus. Nilai kemampuan membaca pemahaman peserta didik pada siklus I adalah sebagai berikut:

Tabel 1. Nilai Kemampuan Membaca Pemahaman Siklus I

\begin{tabular}{lccc}
\multicolumn{1}{c}{ Kategori } & $\begin{array}{c}\text { Siklus I } \\
\text { Pertemuan 1 }\end{array}$ & $\begin{array}{c}\text { Siklus I } \\
\text { Pertemuan 2 }\end{array}$ & Siklus I \\
\hline Rata-rata Klasikal & 67,14 & 71,06 & 69,10 \\
\hline Ketuntasan Klasikal & $41.94 \%$ & $61.29 \%$ & $48.39 \%$ \\
\hline Nilai Terendah & 41.6 & 45.83 & 45.83 \\
\hline Nilai Tertinggi & 85.42 & 87.5 & 83.43 \\
\hline
\end{tabular}

Merujuk pada tabel 1, keempat kategori mengalami peningkatan pada tiap pertemuan. Nilai siklus I didapatkan dari rata-rata nilai tes kemampuan membaca pemahaman pertemuan 1 dan 2 tiap peserta didik. Nilai rerata yang didapatkan peserta didik pada Siklus I yaitu 69,1. Nilai tertinggi yang diperoleh yaitu 83,35, sementara nilai terendahnya adalah 45,83. Sebesar 48,39\% (15 peserta didik) telah mencapai katergori tuntas (Nilai $\geq 70$ ). Indikator kinerja penelitian pada siklus ini belum tercapai, maka penelitian dilanjutkan ke siklus berikutnya. Tabel 2 menampilkan nilai kemampuan membaca pemahaman peserta didik pada siklus II.

Tabel 2. Nilai Kemampuan Membaca Pemahaman Siklus II

\begin{tabular}{lccc}
\hline \multicolumn{1}{c}{ Kategori } & $\begin{array}{c}\text { Siklus II } \\
\text { Pertemuan 1 }\end{array}$ & $\begin{array}{c}\text { Siklus II } \\
\text { Pertemuan 2 }\end{array}$ & Siklus II \\
\hline Rata-rata Klasikal & 75,86 & 77,81 & 76,84 \\
\hline Ketuntasan Klasikal & $80,65 \%$ & $83,87 \%$ & $83,87 \%$ \\
\hline Nilai Terendah & 52,08 & 60,42 & 60,42 \\
\hline Nilai Tertinggi & 89,58 & 91,67 & 87,5 \\
\hline
\end{tabular}


Merujuk pada tabel 2, keempat kategori mengalami peningkatan pada tiap pertemuan. Nilai siklus II didapatkan dari rata-rata nilai tes kemampuan membaca pemahaman pertemuan 1 dan 2 tiap peserta didik. Nilai rerata yang didapatkan peserta didik pada siklus II yaitu 76,83. Nilai tertinggi yang didapatkan yaitu 87,5 , sementara nilai terendahnya adalah 60,42 . Sebesar $83,87 \%$ (26 peserta didik) telah mendapat nilai $\geq 75$. Indikator kinerja penelitian telah terpenuhi dalam siklus ini. Hal ini berarti penelitian tidak perlu dilanjutkan pada siklus selanjutnya.

Data nilai kemampuan membaca pemahaman memperlihatkan adanya peningkatan tiap siklusnya. Peningkatan tersebut terlihat pada nilai rerata, persentase ketuntasan klasikal, nilai terendah, dan tertinggi. Tabel 3 menampilkan peningkatan nilai kemampuan membaca pemahaman anatar siklus.

Tabel 3. Perbandingan Hasil Tes Kemampuan Membaca Pemahaman

\begin{tabular}{lcc}
\hline \multicolumn{1}{c}{ Keterangan } & Siklus I & Siklus II \\
\hline Nilai Terendah & 45,83 & 60,42 \\
Nilai Tertinggi & 83,35 & 87,5 \\
Nilai Rata-rata Klasikal & 69,1 & 75,84 \\
Persentase Ketuntasan Klasikal & $48,39 \%$ & $83,87 \%$ \\
\hline
\end{tabular}

Merujuk pada tabel 3, persentase kentutasan klasikal pada siklus I mencapai 48,39\% (rerata 69,1), meningkat pada pada siklus II menjadi 83,87\% (rerata 75,84 ). Inikator kinerja penelitian (80\%) memang telah terpenuhi pada siklus kedua, tetapi masih tedapat 5 peserta yang memiliki nilai kemampuan membaca pemahaman dibawah nilai KKM (belum tuntas). Hal ini dikarenakan mereka adalah peserta didik yang sangat aktif atau cenderung bergerak, sehingga mereka sulit untuk memperhatikan penjelasan guru. Hal tersebut mengakibatkan mereka sulit untuk menerima atau menyerap instruksi atau informasi yang diberikan guru. Solusi dari masalah ini adalah dengan melakukan pendekatan secara pribadi pada kelima peserta didik tersebut.

Temuan pada PTK ini adalah meningkatnya partisipasi aktif peserta didik dalam pembelajaran membaca pemhaman. Peningkatan ini dikarenakan pada tahap diskusi (mengerjakan LKPD secara berkelompok) dalam langkah/sintaks model pembelajaran STAD membiasakan peserta didik untuk secara aktif terlibat secara langsung menemukan informasi dalam suatu bacaan. Hal tersebut mengakibatkan meningkatnya kemampuan membaca pemahaman peserta didik kelas III SD Negeri 2 Dibal tahun ajaran 2020/ 2021. Hal ini sesuai dengan pendapat dari Khalid Khalaf yang menjelaskan bahwa adanya keterlibatan peserta didik dalam pembelajaran menjadikan pembelajaran lebih berkesan (pembelajaran bermakna), sehingga dapat mengembangkan/ meningkatkan keterampilan, pengalaman, dan kemampuan peserta didik.

Implementasi model pembelajaran STAD dalam pembelajaran membaca pemahaman pada peserta didik kelas III SD Negeri 2 Dibal menjadikan peserta didik lebih semangat dalam mengikuti pembelajaran. Hal ini dikarenakan peserta didik bekerja secara berkelompok, oleh karena itu antarpeserta didik bisa saling memotivasi untuk memahami suatu materi. Selain itu, melalui implementasi model pembelajaran STAD peserta didik lebih berani untuk menyampaikan pendapatnya. Langkah model pembelajaran STAD pada tahap diskusi dan konfirmasi yaitu ketika peserta didik secara berkelompok menyampaikan hasil diskusi kelompoknya menjadikan peserta didik terlatih dan terbiasa untuk berani menyampaikan ide/temuannya. Termuantemuan tersebut sejalan dengan pendapat Huda dan Shoimin mengenai kelebihan dari model pembelajaran STAD. Kelebihan model pembelajaran STAD yang dimaksud adalah 1) Peserta didik aktif membantu dan memotivasi semangat untuk berhasil 
bersama; 2) Berperan aktif sebagai untuk lebih menigkatkan keberhasilan kelompok; 3) Interaksi antar peserta didik seiring dengan peningkatan kemampuan mereka; 4) Meningkatkan kecakapan individu dan kelompok.

Peningkatan ketuntasan klasikal tiap siklusnya membuktikan bahwa model STAD dapat meningkatkan kemampuan membaca pemahaman peserta didik kelas III SD Negeri 2 Dibal tahun ajaran 2020/2021. Persentase kentuntasan klasikal siklus pertama yaitu $48,39 \%$, kemudian naik menjadi $83,87 \%$ pada siklus kedua. Hal ini selaras dengan penelitian Edy Noviana yang menunjukkan bahwa penerapkan model pembelajaran STAD (Student Team Achivement Division) dapat meningkatkan hasil belajar PKN Kelas IV SD Negeri 79 Pekanbaru. Peningkatan ini terlihat pada presentase ketuntasan klasikal pratindakan yaitu $33 \%$, kemudian menigkat pada siklus pertama menjadi $72,5 \%$, dan meningkat kembali menjadi $87,5 \%$ pada siklus kedua. Selain itu, penelitian Ma'rifatul Laili menunjukkan bahwa model pembelajaran Metode Overview, Ask, Read, Write, Evaluate, Test (OARWET) terbukti dapat meningkatakan kemampuan membaca pemahaman peserta didik. Peningkatan ini dapat dilihat pada presentase ketuntasan peserta didik siklus pertama sebesar $73,33 \%$ dengan nilai rerata 74 . Persentase ketuntasan siklus kedua yaitu $100 \%$ dengan nilai rerata 85,55 . Persentase ketuntasan siklus ketiga yaitu $100 \%$ dengan nilai rerata 87,33 . Kaitan antara hasil tes kemampuan membaca pemahaman, temuan, dan penelitian relevan memperkuat bahwa tindakan dalam penelitian ini terbukti dapat meningkatkan kemampuan membaca pemahaman peserta didik. Oleh karena itu, model pembelajaran STAD (Student Team Achivement Division) terukti efektif digunakan sebagai alternatif untuk meningkatkan kemampuan membaca pemahaman peserta didik.

\section{SIMPULAN}

Berdasarkan hasil penelitian dan pembahasan, dapat disimpulkan bahwa penggunaan model pembelajaran STAD (Student Team Achievement Division) dapat meningkatkan kemampuan membaca pemahaman peserta didik kelas III SD Negeri 2 Dibal, Boyolali tahun ajaran 2020/2021. Implikasi penelitian ini secara toretis menambah wawasan mengenai penerapan model STAD pada pembelajaran membaca pemahaman dan dapat pula dijadikan referensi atau bahan pertimbangan bagi penelitian selanjutnya dengan masalah yang serupa. Selain itu, hasil penelitian ini juga memberikan implikasi praktis pada proses pembelajaran yaitu terwujudnya pembelajaran membaca pemahaman yang efektif dan evisien, serta meningkatnya kemampuan membaca pemahaman peserta didik kelas III.

\section{DAFTAR PUSTAKA}

Desmita. (2012). Psikologi Perkembangan Perserta Didik. Bandung: PT Remaja Rosda Karya

Edi, N. (2018). Penerapan Model Pembelajaran STAD untuk Meningkatkan Hasil Pembembelajaran PKN Siswa Kelas IV SD Negeri Pekanbaru. Jurnal Pendidikan Guru Sekolah Dasar Fakultas Keguruan dan Ilmu Pendidikan Universitas Riau, 7(2), 204-210.

Huda, M. (2015). Model-model Pengajaran dan Pembelajaran. Yogyakarta: Pustaka Pelajar.

Khalid Khalaf, B. (2018). Traditional and Inquiry-Based Learning Pedagogy: A Systematic Critical Review. International Journal of Instruction, 11(4), 545-564.

Khundaru, S. (2014). Pembelajaran Keterampilan Berbahasa Indonesia. Yogyakarta: Graha Ilmu.

Ma'rifatul Laili, Z. (2016). Peningkatan Kemampuan Membaca Pemahaman Melalui Metode Overview, Ask, Read, Write, Evaluate, Test (OARWET) Pada Siswa Kelas V SD. Kalam Cedekia PGSD Kebumen, 4(3.1), 333-338. 
Mulyasa, E. (2008). Kurikulum Berbasis Kompetens. Bandung: PT Remaja Rosdakarya.

Rusman. (2014). Model-model Pembelajaran Mengembangkan profesionalisme Guru. Jakarta: PT Rajagrafindo Persada.

Saepudin, E. (2015). Tingkat Budaya Membaca Masyarakat. Jurnal Kajian Informasi \& Perpustakaan, 3(2), 271-282.

Slavin, R. E. (2015). Cooperative Learning Teori, Riset dan Praktik. Bandung: Nusa Media.

Sugiyono. (2010). Metode Penelitian Pendidikan (Pendekatan Kuantitatif, Kualitatif dan $R \& D)$. Bandung: Alfabeta.

Shoimin, A. (2014). 68 Model Pembelajaran Inovatif dalam Kurikulum 2013. Yogyakarta: Ar-Ruzz Media. 